\title{
The role of implicit contracts: Building public works in the 1840s in Portugal
}

\author{
Maria Eugénia Mata* \\ Universidade Nova de Lisboa, Portugal
}

\begin{abstract}
This article studies financial schemes for building public works in the $1840 \mathrm{~s}$. The study of the Portuguese case clearly illustrates the importance of implicit contracts with governments in peripheral Europe, shedding light on solutions for financing the provision of public goods. Building roads and railways seems to have been the fruit of an implicit contract behind the tobacco monopoly in a country involved in social turmoil and civil wars. Reputation effects are called to explain the relevant range of the partners' negotiations, to reject the traditional historiography based on wrong management and speculation in a period of savage capitalism.
\end{abstract}

Keywords: financing public goods; feasibility of self-enforcement contracts; implicit contracts; bargaining; business in nineteenth-century peripheral Europe

\section{Implicit contracts: financial schemes for building public works}

This article seeks to study a Portuguese company of the 1840 s that was committed to building public works under a written but open contract with the government, in order to illustrate how informal agreements, implicit elements, unwritten clauses or codes of conduct powerfully affect the life and behaviour of firms. An implicit contract is an informal agreement that is reached through non-verbal behaviour rather than by explicit words. It is a contract in which the terms may not be expressed, either orally or on paper. Such contracts are adopted because any explicit contract must specify ex ante conditions or clauses that may be checked ex post. Implicit contracts, on the other hand, help to 'circumvent difficulties in explicit contracting' (Baker, Gibbons, \& Murphy, 1997, p. 26). The main features studied in implicit contracts theory are those of observability, complexity and enforcement. By definition, a contract is an agreement between two parties in which each assumes obligations toward the other (Brousseau \& Glachant, 2002). As explicit contracts require gathering extensive information, agreeing on enforcement mechanisms and frequently hiring expert legal advisors in a difficult process of clauses for mutual observation of possible escapes, the benefits of implicit contracts stem from leaving certain conditions unspecified, or not formally articulated. Outcomes may not be evaluated ex post or specified ex ante. Under these conditions, the costs to parties of solving particular contracting problems exceed their gains from doing so and the optimal contract is left deliberately vague (Shwartz, 1992, p. 78). Note that business relationships frequently rely on trust rather than contracts and may be extremely durable, according to business historians (Jones, 2000, p. 352). If a written contract reveals clear omissions,

*Email: memata@fe.unl.pt 
references to subsequent agreements, or includes issues still to be specified, one may assume the presence of a fair amount of trust between the parties involved.

Building roads and railways in the 1840s was an interesting business in England (for the globalisation perspectives on public works, see O'Rourke \& Williamson, 1999). Private companies performed important roles in financial markets, risking capital to build them. Speculation and expected profitability in exploiting their services were closely linked, as exclusion of consumers was possible, making the economic sector a coveted business for private initiative (Hibbs, 1991, pp. 1-7). Revenues from freight and passenger rail travel, as well as revenues from tolls collected on vehicles and cattle using roads provided good rewards for investment (Barker \& Gerhold, 1993).

In some regions of the world, the business of building railways and roads was not attracting private initiative, particularly in the most peripheral European countries (including France; see Jones, 1995). In Portugal, economic underdevelopment, scarcity of capital and domestic political problems discouraged private initiative from undertakings of this nature. The reasons are beyond the scope of this article, but may be related to the social and political turmoil that overshadowed economic life in Portugal from the turn of the century. Three Napoleonic invasions, the independence of colonial Brazil in 1822 and the 1832-1834 civil war brought great disarray to businesses, making cultural and social elites conscious of Portugal's late industrialisation in comparison to other countries, and the need for technical progress and transport facilities to catch up with Europe (Psalidopoulos \& Mata, 2002). In order to encourage economic development and implement a liberal political regime, in the 1840 s the government embarked on a programme of public works to build transportation facilities to promote economic activities. The idea was to stimulate business and domestic production. ${ }^{1}$

However, an impoverished central state lacked the money to invest in building the roads and railway as collective facilities under public provision. Moreover, the current government did not fully support a public character for the project. Transportation technology demanded high fixed sunk costs for building the infrastructures, and, according to the prevailing liberal ideology of the time, building should be a private business. The ideal solution in the government's opinion was to invite a private company that could raise sufficient capital for the purpose of carrying out the task in co-operation with the central state, under the stimulus of government. In studying this solution we are able to shed light on the financial schemes that frequently prevailed in poor countries of peripheral Europe for such undertakings. This study also helps to equate decisions on the alternative ways of financing public goods and their services, as the specialised literature offers sound reasoning on this subject (Roberts, 1987, pp. 420-437). In the present, as in the past, the alternatives considered by governments for financing public works include raising existing taxes, levying new ones, public borrowing or even financing by means of lotteries (Greenberg, 1975, pp. 168-195; Guesnerie, 1979, pp. 393-421; Morgan, 2000, pp. 761-784; Wright, 1977, pp. 51-58). Political decisions are always required in this regard and depend on the real constraints that a government faces. The effects on welfare may be considered as the most relevant to be studied (Loehman \& Whinston, 1999, p. 1971), but the feasibility of the solution(s) pursued is perhaps the most decisive aspect to be considered, as this Portuguese company from the 1840s illustrates regarding the need for implicit contracts. Whenever prospects of uncertainty are very high, the contracts must trade off optimal risk-sharing against productive efficiency, because of unknown costs, business cycles, or other uncertainties.

Observing implicit contracts directly is difficult because of their implicit nature. The written contract with the government established how the Portuguese Public Works 
Company (Companhia das Obras Públicas de Portugal) should advance capital, build the desired facilities and wait for the return on investment, and how the advanced capital should be considered as a loan to the government. The central state would pay back the capital at a later date, when it would be more convenient for the exchequer. In the meanwhile interest should be paid on the loans. As a result, taxation was also called into the mix, through the creation of a contribution for roads, whose revenues were expressly earmarked for the payment of interest on the capital advanced by the Company. The interest in this exercise resides in the appraisal of today's policies in building public works.

How, then, to implement this model in a country that was scarce of capital and private firms? If the government wanted to select a private company to contract for building public works, it should seek a financial group through a system of auctions, which applies very well to selecting firms for public utilities or even to borrowing. In fact, according to the theory of contracts, competition amongst the competitors embodied in the auction mechanism allows the government to extract expected revenue that increases with the number of bidders (Salanié, 1994, 1998). When the number of participants tends to infinity, at the limit it should be possible for the government to appropriate all the surplus of the business.

In Portugal, however, the historical case of the Companhia das Obras Públicas illustrates the particular situation of implementing the model with a limited number of possible partners, as financial groups were not abundant - a situation that may occur in many other historical scenarios. At this time a strong financial group existed in competition with two others. One was the Bank of Lisbon, the first Portuguese bank. The second was the group which was involved in the business of Portuguese foreign public debt conversion, Folgosa, Junqueira, Santos \& Company. The third was the group selected, the recipient of the tobacco business, a traditional state monopoly. This tobacco group created the National Trust Company (Companhia Confiança Nacional) for lending funds to government and also the Company of Public Works for implementing public works. It was a strong financial group in Portugal (Valério, 1984).

The founders of the Portuguese Company of Public Works were therefore very nearly the same men who founded the Portuguese Tobacco, Soap \& Gunpowder Company in the same year of 1844. As mentioned above, through this other Company they received the monopoly for producing and trading those goods in Portugal, from 1844 to 1858, and they substituted the National Trust Company (Companhia Confiança Nacional) for the Portuguese Tobacco, Soap \& Gunpowder Company in providing a loan to the government, amounting to about $£ 888,889$, which resulted from the terms of the tobacco contract.

With the Public Works Company, the business also included lending capital to the Portuguese central state, this time for building the public works. As soon as the new roads were open, the Company would receive the tolls collected from them and apply those revenues to the construction of the railway. Finally, at the end of all the construction, it would receive the advanced capital.

The role of explicit and implicit contracts cannot, therefore, be disregarded if one wants to understand why building of public works was awarded to one of the financial groups or to discuss the feasibility of the solution for financing public goods in general. The article explains the connections between government lending and the other important undertaking that was awarded to the same financial group, the monopolistic manufacture of tobacco products. The interest of the exercise may lie in the appraisal of present-day proposals for building high-cost public infrastructures in a context of severe budget constraints. 
This article argues that the main aim of the group had been to secure the highly profitable business of tobacco processing. However, the government awarded all of the business to these companies in a 'lump': tobacco, for a fixed annual 'rent' to fund the public budget, public debt conversion for minimising public expenditure, and building transport facilities, to implement the government's political programme. So, although explicit contracts never explicitly mention any links between the three businesses, it is possible to describe the government as the principal, and the Portuguese Company for Public Works as its agent for building the public works (mainly roads and rail).

As an explicit contract actually did exist, on tobacco, lending to the government and roads were the rest of a 'package deal' of mixed business opportunities. Government and companies were performing their role as partners in a business.

The Company was a failure. Its building activity lasted a mere two years, coming to a halt in 1846. Traditional Portuguese historiography portrays this company as an example of government protectionism and political corruption. According to this interpretation, poor management and corruption led to strained political relationships with the government, and were the reasons that the building activity came to an end (Peres, 1971). It identifies the Company with the seven capitalists of the Board, accused of representing the untamed face of savage capitalism. According to other interpretations, the Company was managed in an efficient and meticulous way and it was liquidated because of a second civil war in 1846-1847, and failure to understand the scope of the business, the role of the implicit contracts behind public works and the complex framework supporting the decisions of the partners (Mata, 1999). The present article seeks to resolve this discrepancy. As the seven capitalists of the Board were very experienced businesspeople, the study of the whole strategy of the financial group they represented will be used to make the accepted contracts more understandable. ${ }^{2}$

\section{Founding the Company}

The Company was founded on 19 December $1844 .{ }^{3}$ The founders were seven wealthy Lisbon traders: Carlos Morato Roma, Francisco Ribeiro da Cunha, Joaquim Honorato Ferrreira, José Maria Eugénio de Almeida, Manuel Cardoso dos Santos, Manuel Gomes da Costa São Romão, and Tomás Maria Bessone. Their personal fortunes were derived mainly from international trade, shipping, and financial enterprises. Some of them were also large landowners (Martins, 1992; Reis, 1993a).

The equity of the Company amounted to about $£ 4,444,444$. However, only $£ 2,680,000$ was actually subscribed. The capital investment of each of the partners was to be made in regular instalments, the first amounting to $5 \%$ and the others $3 \%$, according to the rules of the statutes. The Company began the building activities with equity amounting to $£ 80,666$, part of it in money, part of it in shares and public bonds. ${ }^{4}$

According to the statutes of the Company, the seven founders would constitute the Board of the Company (Direcção da Companhia), under the presidency of Carlos Morato Roma, the most erudite of them. ${ }^{5}$ They all were to deposit their individual shares, each amounting to about $£ 6,666$. Although the statutes allowed for the possibility of enlarging the Board to 11 members, this would never happen.

The Board began its functions on 15 March 1845. Each of them was to receive $7 \%$ of the net profits as remuneration for his management work. It is important to note that the statutes of most of these companies or societies were very similar, and the rules did not establish a real control of the businesses by the shareholders. Moreover, the rules were also unclear on the transparency of accounting, meaning that the auditors served at the pleasure 
of the Boards of companies' administrators and founders, leaving the shareholders as simple capital providers. The tobacco group had no significant participation in the capital of the Bank of Lisbon and the financial group of the Bank of Lisbon had a minor participation in the capital of the two twin companies (National Trust and Public Works).

The Board was to report the accounts of the activities annually, in January. A general report was to describe the financial situation of the Company, then to be commented upon by the General Commission of the Company, which represented all of the shareholders. This General Commission was comprised of 40 members selected from amongst those having shares amounting to $£ 4,444$. Twenty of them were co-opted and the other 20 were to be appointed by the Board. The other shareholders of the Company would have access to the accounts for only three days. In the event of a need to fill a vacancy on the Board, the statutes recommended that other members of the Board would appoint one of the members of the General Commission of the Company.

It is possible to recognise that traditional historiography is correct in stressing the small amount of capital that was underwritten when the Portuguese Company of Public Works was founded, as it obtained a loan from its twin company National Trust (which belonged to the same financial group), amounting to $£ 65,244$. This fact illustrates well the scarcity of capital that was available to the group and how interrelated the companies were in the triple business of paying the tobacco rents, lending to the government, and building public works, respectively. The agency costs for providing the guarantee were transferred to the Company that was devoted to public debt operations, using public bonds amounting to about the same value, $£ 6,666$.

Regarding the life span for the Company, the statutes stipulated that 'The life span of the Company is undefined; but the Company may be dissolved after the approval of such a proposal from the Board in an Assembly comprising the members of the Board, the General Commission and the 20 largest partners.' The statutes are available at the Arquivo Histórico do Banco de Portugal.

\section{The business endeavours}

At the time, Portugal was an underdeveloped country lagging behind most of the rest of Europe. The first half of the century was very difficult environment for economic growth. The three French invasions destroyed agriculture and used vast financial resources to expel the foreign troops. British military assistance to Portugal for this purpose evolved into a genuine military occupation, as the king and royal family relocated to colonial Brazil, to the new capital established in Rio de Janeiro, in order to escape political capitulation in Lisbon, and Brazil's independence left the mother country confined to its continental mainland. Deprived of the benefits of colonial trade, some juridical adjustments were adopted in order to implement a market for land, while economic modernisation in most European countries contrasted with Portugal's internal difficulties. Poor land, scarcity of mineral depositis, and illiteracy joined forces to explain the poor business opportunities for private initiatives (Reis, 1993b). Moreover, social turmoil in the 1830s resulting from a civil war between Pedro, the emperor of Brazil, and Miguel, his brother, further exacerbated the public debt. It is quite clear that lack of confidence and unsuccessful businesses were the rule. With the exception of high rewards from lending to the government, private capital found few profitable business opportunities.

The idea was also to build the first railway line, linking the Portuguese capital to the Spanish border, easing the transportation of freight and people amongst regions in facilitating overland contacts with Spain and France through the Pyrenees. The normative 
judgement on the role of government to help in establishing beneficial exchanges posed problems to the Portuguese politicians of the 1840s. Transportation facilities were regarded as a diagnostic tool to foster economic growth in a context of social utility (Zerbe \& McCurdy, 1999). As the remedy for externalities and market failure in the provision of public goods might be found in the public sector's involvement, the general concept of the plan for the Portuguese roads was to transform Lisbon, the capital of the Portuguese kingdom, into the hub of the whole network. Lisbon was, in fact, the main urban centre and also the main economic and financial city of the country. As it is located on the Atlantic and in the middle of the length of the Portuguese coast, the plan for roads had a half-star shape, crossing the main cities of the whole territory, from north to south, from west to east. Easy transport and decreasing information costs were considered useful for fostering industrialisation. In the perspective of the government headed by the Duke of Terceira, with an enthusiastic role for the Minister of Domestic Affairs, Costa Cabral, transportation facilities were a normative prescription for growth. As Zerbe and McCurdy (1999, p. 560) put it, it was 'a quasi-scientific full-scale test with prescription of cures'.

\section{Analysing the explicit contracts: the legal and juridical background}

The Company entered into the contract with the government on 1 March 1845. As was usual in the business of public works at the time, ${ }^{6}$ the Company was also required to build the railway from Lisbon to the Spanish border, to improve the seaport of Lisbon, to build a road around the city of Lisbon, a prison in the capital, a customs house in Oporto, and other public works that the government would decide upon over the next three years. The government would always approve all plans and assess all of the work. These open elements in an agreement of an implicit nature are a further indication of confidence in future understanding, as well as a recognition that the ex ante specifications and ex post verification were prohibitively and unnecessarily expensive.

In order to avoid adverse selection or moral hazard for the contract, the government established the deadlines for completing these projects: ten years for the railway, eight years for the roads, five years for the seaport of Lisbon, the customs house of Oporto, the circuit road of Lisbon and the prison, and eight years for other public works that would follow. Deadlines for the roads and railway should be calculated from the date of the law that approved the contract with the government. For the other public works, deadlines should be calculated from the dates of the approval of their plans. Work on building the roads should begin within a year and continue without interruption. As a guarantee for deadlines, public debt bonds amounting to about $£ 6,666$ should be deposited in the Junta do Crédito Público, but interest would be paid on the capital of this guarantee deposit.

The same law created a new tax to provide money for these roads and the railway (contribuição para estradas). The duration of the tax was also limited to ten years, as it was an extraordinary tax, composed of two parts: the provision of one work-day four times a year by every Portuguese male aged 12 to 60 , with the exception of disabled individuals and soldiers, and a $20 \%$ surtax on the main Portuguese income tax (décima). The corvée labour could be deferred through the payment of a daily wage of 4.4 shillings (100 réis), for each day of work. ${ }^{7}$

According to the Company's archival accounting, the amount of the tax that was collected in each region of the country was turned over to the local agents of the Company, direct and immediately. This means that it was supporting the payment of interest to the Company. The Company was to invest capital and in return would receive public debt bonds that would enjoy all the usual advantages of public debt, namely an 
interest rate of $6 \%$, net of taxes. The invested capital was to be paid by certain deadlines ranging from 30 to 60 years in annual instalments. The government was to allocate $£ 133,333$ in each annual budget to cover these payments, beginning in the 1846-1847 fiscal year. ${ }^{8}$ The amount would be increased if it was deemed necessary.

The revenue collected in tolls was to be used to support the amortisation of roads or even to build new ones. ${ }^{9}$ The Company thus received the revenues of both the newlycreated road tax, which were collected by the government, ${ }^{10}$ and those collected in tolls. ${ }^{11}$ The use of other traffic revenues such as shipping tolls, were to be established in special agreements between the Company, performing as agent, and the government, performing as principal. These revenues were to be divided into three parts, two of them going to the Company and the remaining third to the public treasury, for 60 years in the case of roads and for other periods to be agreed upon in the case of other public works.

Also included was the possibility of awarding the Company the monopoly of all postal services in the country. In fact, the Company had the right to establish carriage services on the roads, for goods and passengers, in addition to the provision of postal services, for 40 years, although other vehicles could also use the roads if they paid the respective tolls. For the railway, the Company was awarded with the operation of its services for a period of 99 years.

The Company was obligated to repair the roads for 60 years, and the railways for a period of 99 years. Other incentives to the Company were stipulated, such as receiving free raw materials from the central state properties, such as wood from public forests. Imported raw materials were to be free of import duties.

As can be seen, the rules of the contract were very complicated and some of them were left undefined. Of course, the contract between the Company and the government was a self-enforcing contract, so defection was assured against by the terms of the contract. It could not rely on external threats (Salanié, 1994). Guarantees was not assured by a third party but by the government itself. It is easy to foresee that much negotiation and renegotiation would be called for throughout the duration of the contract, as the government was simultaneously a partner and the enforcer of contracts (for a case study of relations between the central state and colonial administration see Sunderland, 1999). This dynamic interaction increases the complexity for non-cooperative outputs.

It should also have been easy to predict the high probability that disagreements would occur, as principal and agent would try to maximise the defence of their own positions, one against the other. If one considers that the group might have been interested only in tobacco and an opportunity for defection, the Company of Public Works should have been estimating the current benefits of not upholding the terms of the contract. However, the Company should also have been considering the costs of future responses to such behaviour. Losing the tobacco contract would be a disaster for the group. So the selfenforcing character of the contract relied on this threat and on the weight the Company gave to future benefits. It worked on an inter-temporal estimate. In a certain sense this was a bilateral monopoly situation, as the government also depended on the payment of the tobacco rent.

The central state had bargaining power, as it acted as leader or principal. From the outset, the central state proposed 'take it or leave it'. The explicit aspects of the written contract correspond to the equilibria of the one-shot trading game (Freddenber \& Tirole, 1991). On waiting for an answer, yes or no, without the possibility for the financial group to propose another contract, the seven capitalists had chosen to accept the whole package of businesses. The agreed aspects were the possible equilibrium between the government and the financial group, as the government needed their financial support in seeking a way 
out of a very difficult situation for the Exchequer, and the group needed business opportunities related to public debt operations and industrial monopoly conditions. The contract was therefore reliable and the optimal policies of the two parties in implementing the contract defined the relevant range of their concessions.

Asymmetric information existed from the beginning. The government tried to hide the financial penury of the central state. The group could disguise its lack of interest in building public works in order to secure the whole set of contracts, especially the tobacco monopoly. Should a dispute arise, it might be more difficult to prove the existence and terms of such implicit aspects.

The life of the Company was very troubled, as the next sections will show, and only two instalments of the subscribed capital were realised. ${ }^{12}$

\section{Structure and management}

The headquarters of the Company were shared with its twin, belonging to the same group, National Trust, in a building located in downtown Lisbon. They shared not only the office space but also the administrative staff. ${ }^{13}$ The recruitment was very meticulous. For administrative clerks it included rigorous examinations in accounting and writing skills. The twin companies shared the common costs of the rent (about 2.66 shillings, 600 réis a month) and the wages on a $50 \%$ basis. However, separate ledgers were kept for the two companies.

The Company had a regional network of local agencies that were located in the capital cities of mainland Portuguese districts and in the Portuguese islands of Madeira and the Azores. This means that the company was an agent in the relationship with the central state, but was the principal in the relationship with the local agents. ${ }^{14}$ Each agent was required to pay the expenditures of the Company in that region and receive the tax on roads that was collected by the regional governmental finance services. For monitoring local agents, both regional government finance services and agents were to inform the Company of the amounts of road tax that had been locally collected.

Central state monitoring included overseeing of local agents' activities by the representative of the government in each of the capital cities of the Portuguese districts. The Company was careful to communicate all these rules to the regional political authorities (governadores civis), to whom the local agents of the Company were introduced. Both the government and the Directors of the Company co-operated to minimise the risk of adverse selection and moral hazard, revealing a meticulous control on the part of both government and Board over the regional structure of the firm. The Directors were very experienced people and could implement the same principles of management that were being used in their other personal businesses.

The agents located in the islands also helped the Company to recruit local labour for the building of public works in mainland Portugal. ${ }^{15}$ The idea was to divert the traditional emigration from the islands to other endeavours, and direct it toward mainland Portugal, where scarcity of labour was a real problem. Political authorities in the islands co-operated with the Company to gather this labour force and relocate workers to work for five years to where the need was most pressing. For this purpose, the Company paid for the roundtrip voyages of the workers and their families. ${ }^{16}$ Should a disabling labour accident occur, the remaining portion of the five-year period would be excused and the worker could return home early.

Most of the network of regional agents was shared with the twin company, the National Trust, from the beginning. From May 1846 on, the regional network of agencies 
was also common to the Tobacco Company. ${ }^{17}$ In fact, wherever there were regional tobacco agents, the two companies' agents were replaced by them. This means that the three companies were independent institutions from a legal point of view, but were very closely interrelated, and their businesses were managed together. The accounting books reveal that each of the companies made local payments on behalf of the other. As this was a mutual procedure, the reason for it resided in minimising administrative costs and managing the available capital, applying it to the most immediate needs of the businesses of each of the twin companies. Ledger entries reveal that these payments were carefully recorded and cleared at the end of each month between the twin companies.

From 1846 on, the Portuguese Company of Public Works opened four agencies abroad: the first in Paris, the second in Seville, the third in London and the fourth in Antwerp. The Board sent abroad one of the Directors, José Maria Eugénio de Almeida, a wealthy and experienced capitalist and landowner, who visited England, France and Belgium to prepare the opening of the four agencies in Europe (Reis, 1993a). The creation of this European network of agencies grew out of the need to purchase technology and recruit two senior engineers for building the public works. Technical paraphernalia such as topographical survey instruments were not available in Portugal, an underdeveloped country, at the time. As for engineers, the Company could count on the Portuguese engineers from the army. They deserve to be studied, as engineering was the new profession of the nineteenth century and provided technical staff for public works.

\section{Technical staff}

According to the Company's books, the two foreign engineers were senior individuals who were responsible for supervising all of the technical aspects involved in the public works. ${ }^{18}$ Four Portuguese senior engineers from the Army were responsible for surveying the works: a lieutenant colonel and three captains. ${ }^{19}$ The works inspector of the Company (João Crisóstomo de Abreu e Sousa) would become Prime Minister of Portugal from 1890 to 1892 . Direct responsibility for regions was assigned to 11 young lieutenant engineers who performed important roles in Portuguese society during the second half of the nineteenth century, and their experience in the Portuguese Company of Public Works was only the start of their professional careers, as their names are connected with many important technical accomplishments throughout the century. ${ }^{20}$

José Vitorino Damásio is perhaps the best known amongst them, as he worked for decades in the Portuguese Ministry of Public Works, supervising the construction of railways and participating in improvements to the port of Lisbon. At the beginning of his career in the Portuguese Company of Public Works he was responsible for the works south of the Douro River.

Upon developing his engineering activities, Carlos Ribeiro also became a renowned geologist and palaeontologist, as public works provided him with the opportunity to study the tertiary basins of the Tagus and Guadiana Rivers throughout his career (Leitão, 2001, pp. 293, 294). In the 1860s he would study Miocene strata and deduce the presence of humankind at a much earlier date than previously argued, presenting his findings at the International Congress of Anthropology in Brussels, 1872 (Rocha \& Kullberg, 2004, p. 32), and becoming a member of the Portuguese Academy of Science. In the Portuguese Company of Public Works he was responsible for roads in the Douro region.

Three other lieutenant engineers, ten sub-engineers and 14 first-class apprentice engineers co-operated with them. Three designers helped in drawing plans for the works. They too were monitored: engineers were not authorised to exceed their technical abilities, 
and only the local agents of the Company could buy instruments locally or make payments.

This was a splendid technical elite of Portuguese society at the time. Most of the engineers rose to the highest positions in the Army during the second half of the century, and constructed important public works throughout the country, which are still in use today. This means that the Company was able to gather not only sufficient management skills, but also enough human capital to succeed in building the public works that were contracted with the central state and government.

\section{Building the contracted public works}

The Company's first year of activity, 1845, was a first phase. The accounts reveal that many studies were developed in order to begin work on the contracted projects. At the same time, this was the moment for implementing the national network of regional agencies amongst the regional capital cities. Works began very soon, in July 1845 , with the acquisition of tools and instruments for the projects. Several roads were improved in the northern province of Minho and around the Portuguese capital city of Lisbon. Many of them employed sub-contracting with other operators. ${ }^{21}$ A coalition made up of three firms also signed a similar sub-contract for building the Oporto-Penafiel road. ${ }^{22}$

The Company was thus a government agency that sub-contracted the works from other private companies, having a simultaneous role as agent of the central state and principal in the relationship with the sub-contractors. They effectively began their works in all these regions and the financial results for the Company were positive. ${ }^{23}$

The Company accumulated capital amounting to $£ 161,333$, earned a profit of $£ 11,555$ as well as net loans amounting to $£ 3,111$ and devoted all this money to works payment for which was to be provided by the central state. It is possible to conclude, then, that the situation of the Company was healthy at the end of its first year, but it was absolutely dependent upon the central state payment for the works built by the Company. As in fact the contract was a self-enforcing one, it was very important that it was respected by the Company, because of reputation effects regarding the monopoly of tobacco, the other business of this financial group. In the long run it was better that the Company respected norms that might not be profitable in the short run. This principle was strictly observed. The Board was aware of the threat that failed payments by the central state could spell the death of the Company. In light of this, they wrote a letter to the Ministry of Domestic Affairs at the end of the year to claim the payment of the government debt to the Company, according to the established contract, but did not interrupt the agreed contracts. Honouring the relational contract informing on the needs means enjoying a greater present value of the long-run stream of expected values. The conditions prevent the Company from unilateral defection because of weak renegotiation-proof forces.

For the historian, implicit contracts are difficult to observe, but it may be significant that the Board did not reveal the financial results of the Company to the General Commission. In a report of 31 January 1846 the Board postponed reporting the results to the General Commission. Although this disclosure was required in the statutes, the Board argued that some 'difficulties related with the foundation of the Company made it impossible to present a true assessment of the transactions in the last year'. The Board was also vague regarding the interest rate on the accumulating government debt to the Company. The interest rate was not given in the established contract and should be set in special conventions still to be agreed upon. Note that transfer policy plays an important role in self-enforcing contracts, as transfers may be seen as an instrument to cure 
compliance problems. In this way the agents realise the maximum bargaining gains on distributing the total utility according to the strategic bargaining solution using transfers. This feature brings rationality to undefined elements in self-enforcing contracts. So, undefined elements in the written contract were becoming decisive for the organisation's behaviour, although they were invisible to outsiders until this moment. As a result, the Board declared only half of the profits. ${ }^{24}$ Considering that a $6 \%$ profit would be considered normal in a first year of activity, the distribution of dividends settled upon was about this rate. The Board communicated to its shareholders a distribution of total dividends corresponding to an interest rate of $6.75 \%$. The payment was to be made through the Bank of Lisbon. Even adding to the distributed dividends the remuneration that should have been paid to the Board for the management tasks they performed according to the statutes of the Company, the total distributed amount was about $64 \%$ of the real profits of the Company. As the theory of contracts applied to firms can explain, organisational behaviour may seem a mystery to observers because implicit aspects 'provide the music to which the members of an organization dance' (Baker et al., 1997, p. 25).

The first half of 1846 represented a second phase in the life of the Company. It was characterised by a strong expansion of explicitly agreed aspects of its activity. The Company decided to undertake the transportation of passengers and goods on the improved or newly-built roads, according to the written rights of the Company in the contract with the government regarding the operation of transportation activities. These were written clauses of the contract, which could thus be easily verified ex post, and transportation also represented a possible reward for the invested capital. For this purpose the Company bought horses in Spain and carriages for passengers and goods in France. A member of the Board went abroad to these countries for this purpose. Agencies of the Company abroad were able to help with these acquisitions. Moreover, the accounts of the Company also reveal the payment of rents for the storage of animals and vehicles.

Construction activities continued in other regions of the country. This time the Company did not sub-contract the works. This may point to a break with further explicit obligations toward other firms in order to be freer in deciding to continue or not. No written clauses regulated this aspect and parties always use their detailed knowledge of their specific situation to adapt to new information. Curiously, this direct building system involved the recruitment of foreign labour. Fifty-eight trained workers from Belgium were hired in Antwerp to build roads and the railroad in Portugal. Special instruments and know-how were also imported from London and Antwerp (including explosives). The Company's books describe the cost of their voyages by freighter.

Although the number of kilometres constructed is not well recorded, it is clear that some roads were under construction or near completion by April 1846, when the Company began buying vehicles and horses and recruiting drivers for the carriages in order to begin transporting passengers. Animals were sheltered and vehicles stored in Oporto and small cities around Lisbon. This makes it clear that the roads suitable for beginning transportation were those around the two main Portuguese cities, a rational strategy, as demand depended on the amount of freight and number of persons to be transported. The maintenance of animals and vehicles near the capital but out of the urban centre also reveals the aim of reducing rents and costs. A report to the shareholders was very optimistic on the prospects for the next year (1846). ${ }^{25}$ In fact, the start-up of the transportation activities was presented as being very profitable as northern Portugal was a populous region, here presented as one of the most densely populated 'in the world'.

However, the assessment of the financial results for the first half of 1846 was essentially the same as that of the previous year. Without any government payment to the Company, 
with the exception of the roads tax, the Company continued to accumulate profits, but new information was quite clearly becoming available. The state debt to the Company already amounted to seven times the profits. ${ }^{26}$

\section{Ending activities}

The Public Works Company was threatened not only by the financial weakness of the Portuguese central state. In the spring of 1846 a popular uprising in protest against taxes erupted in the province of Minho - the exact region where roads were ready to go into operation. This revolt, which is usually associated with the name of Maria da Fonte, one of the principal revolutionaries, translated into riots throughout the northern regions of Portugal, requiring a military response from the government. By the autumn the unrest had escalated into a true civil war countrywide. It was necessary to suspend the convertibility of the notes of the Bank of Lisbon, as a generalised lack of confidence provoked a bank run.

The civil war affected almost every region of the country until the summer of 1847 . The central government of Lisbon needed to defeat a northern government that was located in Oporto. Great public expenditure was required to control the political and military situation.

The consequences for the Company were mixed. They were disastrous, on the one hand, as not only was the Company unable to continue construction because of the social unrest and political turmoil that prevailed in the country, but it also lost the revenues from the (uncollected) road contribution. On the other hand, the war alleviated the selfenforcing character of the contract, because reputation was now less valuable if the Company wished to renege. The Company reduced its building activities to almost nothing. Every economic activity in the kingdom was affected by the reduced collection of the road tax coupled with the need for higher military spending. The government needed this tax revenue in order to meet the military expenditures, but in many regions contributors who could pay refused to. In July 1847 the books of the Company even record that the amount of the contribution on roads in the district of Aveiro had been lost, as it had been stolen by revolutionaries.

From theoretical approaches it is very well known that facing such prospects of uncertainty, the group would want to pay less because the state of the world was unfavourable. ${ }^{27}$ It is difficult to say for certain which of the contractors was the more riskaverse, but very probably it was the Company. The other partner, the government, might not accept defection, but in this case both found it mutually advantageous to renegotiate in order to avoid inefficiency, because the civil war (the state of the world) provided an unfavourable environment. In these circumstances this was particularly true. As it was difficult to foresee the duration of the political and military problems, one may say that the interaction was being repeated as the adjustment of the contract could be accomplished according to the political facts.

In practice, however, the problem was not only the civil war. Even without the hostilities the business of the Company was threatened because the government was already failing to meet the explicit financial obligations it had assumed, and there was no other enforcer for the contract than the government itself and the self-enforcement mechanisms. Because of the civil conflict, the government had no funds to pay off the public works, which should be regarded as money borrowed from the Company, according to the explicit clauses. It was absolutely clear, therefore, how the government's inability to solve its established commitments to the Company accumulated into a huge 
unrecoverable debt. The war also meant that private information was widely dispersed throughout the economy and both parties had their share of information on the generalised social turmoil, making evident the technical failure of the Company.

Renegotiations legally confirmed this situation by allowing the payment of the debt of the central state to the Company through a special fund (Decree of 19 November 1846). Maximising the sum of bargaining gains always requires effort, and the effort levels are pareto-optimal. This fund (Fundo Especial de Amortização) was created by law for liquidating the debt to the Company (Decree of 1 October 1846). It was to issue $5 \%$ promissory notes to the Company, which the Bank of Portugal would then transform into $5 \%$ domestic bonds, quoted at a $62 \%$ rate in financial markets, in a process that had several consequences that were very relevant for politics in Portugal (Mata \& Valério, 1988).

This solution translates into a welfare-improving point in the contract curve between the parties, dominated by the agent's compliance constraint. One party pays the other by transfers. As the payment of the tobacco rent by the related tobacco company was a decisive factor for the survival of the government, the interest of the $5 \%$ promissory notes amounted to the transfer of the distribution of the bargaining gains that could be credibly agreed to in the new political situation. The creation of the fund should, therefore, allow for a maximisation of total utility for the partners, as it provided the equilibrium for the repeated bilateral trading game.

The technical insolvency of the Company was established and the only thing to be done was to liquidate its activities and operations. In the autumn of 1846 and winter of 1847 the Company sold the traction animals it had bought in Spain for road transportation to the Municipal Police of Lisbon.

The Company also cancelled prevailing sub-contracts. ${ }^{28}$ The only effort for construction was the conclusion of some roads in the north of the country before August 1847, according to the accounting daybook of the Company, which also registers compensation, with the amounts of money advanced to the builders. Once more, in the long run it was better that the Company respected norms that might not be profitable in the short run. By that time only about $50 \mathrm{~km}$ of the long road connecting Lisbon and Oporto had been completed. No more accounting movements can be found describing the payment of expenditures related to land expropriations, studies or planning. The usual entries describing imports of equipment and tools from abroad also disappeared from the accounting books. The Company ceased its activity building public works. ${ }^{29}$ In the closing period, which lasted until the end of 1847 , the Company also paid the agents in each of the Portuguese districts. Curiously, in 1848 these agents continued to make small expenditures locally. However, they obtained the funds from the local agencies of the Bank of Portugal that was founded in 1847 in a merger between one of the twin companies, the National Trust, and the Bank of Lisbon. It is possible to say when the shared office of the twin companies was closed: in October 1848 the furniture was sold to the Bank of Portugal, whose head office was located close to the building where the two companies had their own.

\section{Conclusion}

The literature available on the Portuguese financial companies of the 1840s fails to embrace the appropriate interpretation of their projects and failures. The Company of Public Works illustrates the narrow set of feasible solutions for private business in building high-cost public infrastructures in less-developed regions under severe budget constraints. Clear rules on the financial schemes are necessary to protect business against the impossibility of enforcing contracts. Current empirical research on implicit contracts may 
be of benefit to business historians. In dynamic repeated businesses the contracts are often incomplete, that is, they do not prescribe an intended behaviour for all events. Managers of implicit contracts must accurately assess the non-contractible outcomes. Maintaining the implicit aspects demands that managers know the payoffs that are supposed to result from the outcomes so they can exercise discretion in deciding whether to honour the implicit contract, or to renege on constraints, after proper evaluation and meticulous judgement of complex situations. As a result, incomplete co-operation between the parties should come as no surprise. Connections with public debt may lead to unstable political frameworks, an issue that Portugal's historical past illustrates and political science may approach using different analytical tools.

\section{Notes}

1. A law of 23 July 1843 declared the government policy of building a vast network of roads throughout the country to serve that goal.

2. Sourced in the Historical Archives of the Portuguese Central Bank (Banco de Portugal).

3. With statutes that were approved by law on 30 December 1844 .

4. As public bonds had a low market price, they were accepted at $56 \%$ and $68.5 \%$ of their nominal value, for $4 \%$ interest rate bonds and $5 \%$ interest bonds, respectively.

5. Deputee and member of the Portuguese Academy of Science.

6. The case of Mexico is very clear (see Connolly, 1999).

7. Studies on work contracts may benefit from labour economics (see Conway \& Breiner, 2005; Medof, 1981).

8. A fiscal year began on 1 July and ended on the following 30 June.

9. The price of tolls varied between about 0.88 shillings ( 2 réis) for each animal and 0.73 shillings (165 réis) for each carriage drawn by four beasts or for the use of any first-class bridge. Pedestrians would pay about 2.2 shillings ( 5 réis).

10. According to the law of 26 July 1843.

11. According to article 30 of the contract celebrated between the Company and the government. The details on the reception of these amounts of money collected by the government were established in the official notice Diário do Governo of 18 Oct. 1845. Historical Archive of the Bank of Portugal.

12. The subscribed capital provided the Company with only $£ 161,333$.

13. Facing the Largo do Pelourinho and Rua do Arsenal, and still exists.

14. For reasons related to special public works on the banks of the Alfeizerão River a special agent was created in the neighbouring village of Sanguinhal, near Bombarral.

15. The labour regime was legally defined by the bulletin of 21 June 1845. Historical Archive of the Bank of Portugal.

16. The daily wage for male adults was established at 7 shillings ( $\$ 160)$.

17. Letters to the regional political authorities from the Board of Directors. Historical Archive of the Bank of Portugal.

18. José Luís Vítor Du Pré and Eugénio José de Gayffier. Historical Archives of the Portuguese Central Bank (Banco de Portugal).

19. Gregório António Pereira de Sousa, the first, and António Lopes Pereira Nunes, Francisco Inácio Mendes and Francisco Isidoro Lino de Moura. Historical Archives of the Portuguese Central Bank (Banco de Portugal).

20. All of their names are preserved in street names in the city of Lisbon.

21. The Count De Claranges Lucotte had a similar contract from the central state, for the OportoBraga, Braga-Guimarães, Guimarães-Oporto and Vila Nova de Famalicão-Viana roads. This first contract was cancelled and gave way to a new one, this time with the Public Works Company, to which the central state transferred this commitment. The substitution of the contract led to the payment of an indemnity of $£ 21,333$ to the Count De Claranges Lucotte. P. Lombré \& Company obtained a similar sub-contract for building the Lisbon-Oporto and Carregado-Caldas roads. Historical Archives of the Portuguese Central Bank (Banco de Portugal).

22. De Claranges Lucotte, Figueiredo Pérry \& Company, and João Leite de Faria. Historical Archives of the Portuguese Central Bank (Banco de Portugal). 
23. According to Mata (1993), the expenditures of the Company amounted to $£ 8,000$ and revenues to about $£ 19,111$, providing a final profit of about $£ 11,000$.

24. $£ 5,777$ and not $£ 11,555$. Ibid.

25. Promulgated on 31 January 1846.

26. $£ 25,111$ and $£ 185,555$, respectively.

27. This occurs even with symmetric information (Salanié, 1994).

28. The Company's ledger records the devolution of an agreed guarantee that a sub-contractor had deposited in consequence of the decision of the Company to desist.

29. The liquidation of the Company was regulated in two decrees, one of 7 November 1849 , the other of 15 May 1850.

\section{Notes on contributor}

Maria Eugénia Mata is Associate Professor in the Faculdade de Economia, Campus de Campolide, Universidade Nova de Lisboa, Portugal.

\section{References}

Baker, G., Gibbons, R., \& Murphy, K. (1997). Implicit contracts and the theory of the firm. NBER Working Papers, 6177.

Barker, T.C., \& Gerhold, D. (1993). The rise and rise of road transport, 1700-1990. Basingstoke: Macmillan.

Brousseau, E., \& Glachant, J.-M. (2002). The economics of contracts: theories and applications. Cambridge: Cambridge University Press.

Companhia das Obras Públicas de Portugal, Documento no. 1, Diário, Historical Archive of the Bank of Portugal.

Connolly, P. (1999). Pearson and public works construction in Mexico, 1890-1910. Business History, $41(4), 48-72$.

Conway, N., \& Breiner, R.B. (2005). Understanding psychological contracts at work, a critical evaluation of theory and research. Oxford: Oxford University Press.

Freddenber, D., \& Tirole, J. (1991). Game theory. Cambridge, MA: MIT Press.

Greenberg, J. (1975). Efficiency of tax systems financing public goods in general equilibrium analysis. Journal of Economic Theory, 11(2), 168-195.

Guesnerie, R. (1979). Financing public goods with commodity taxes - tax-reform viewpoint. Econométrica, 47(2), 393-421.

Hibbs, J. (1991). The liberalisation of the British bus and coach industry: an uncompleted enterprise. Economic Notes, 38, 1-7.

Jones, G. (2000). Merchants to multinationals. Oxford: Oxford University Press.

Jones, J. (1995). Un siecle de politique des transports en France, 1830 à 1975. Paris: Celse.

Leitão, V. (2001). The travel of the geologist Carlos Ribeiro (1813-1882) to Europe, in 1858. Comum. Inst. Geol. E Mineiro, 88, 293--300.

Loehman, E., \& Whinston, A. (1999). Welfare implications of alternative methods for financing public goods. Econométrica, 39(4), 1971.

Martins, C.A. (1992). Opções económicas e influência política de uma família burguesa oitocentista: o caso de João Romão e José Maria dos Santos. Análise Social, 116-117 (XXVII), 2, 3, 367-404.

Martins, J.P.O. (1956). Banco. In Economia e finanças. Lisbon: Guimarães \& C ${ }^{a}$ Editores.

Mata, C. (1993). O Banco de Portugal: esboço histórico. Boletim do Banco de Portugal, 1 and 2.

Mata, M.E. (1999). A companhia das obras públicas de Portugal. Estudos de Economia, XIX(1), 43-65.

Mata, M.E., \& Valério, N. (1988). O fundo especial de amortização e o caminho-de-ferro do Norte 1846-1860. Revista de História Económica e Social, 24, 77-87.

Medof, J. (1981). Involuntary terminations under explicit and implicit employment contracts. NBER Working Papers, 634. Available at http://ssrn.com.

Morgan, J. (2000). Financing public goods by means of lotteries. Review of Economic Studies, 67(4), $761-784$. 
O'Rourke, K., \& Williamson, J. (1999). Globalization and history: the evolution of a nineteenthcentury Atlantic economy. Cambridge, MA: MIT Press.

Peres, D. (1971). História do Banco de Portugal, 1821-1846. Lisbon: Banco de Portugal.

Psalidopoulos, M., \& Mata, M.E. (Eds.). (2002). Economic thought and policy in less developed Europe: the nineteenth century. New York: Routledge.

Reis, J. (1993a). José Maria Eugénio de Almeida, um capitalista da Regeneração. In $O$ atraso económico português 1850-1930 (pp. 181-226). Lisbon: Imprensa Nacional Casa da Moeda.

Reis, J. (1993b). The historical roots of the modern Portuguese economy: the first century of growth, 1850s to 1950s. In R. Herr (Ed.), The new Portugal: democracy and Europe (pp. 126-148). Berkeley, CA: University of California.

Roberts, R.D. (1987). Financing public goods. Journal of Political Economy, 95(2), 420-437.

Rocha, R.B., \& Kullberg, J.C. (2004). A geologia na toponímia e na história da cidade de Lisboa. In $4^{a}$ s Jornadas de Toponimia da Cidade de Lisboa (pp. 29-50). Lisbon: CML.

Salanié, B. (1994). Théorie des contracts. Paris: Economica.

Salanié, B. (1998). The economics of contracts. Cambridge, MA: MIT Press.

Shwartz, A. (1992). Legal contract theories and incomplete contracts. In L. Werin \& H. Wijkander (Eds.), Contract economics. Oxford: Blackwell.

Stäler, F. (1998). Economic games and strategic behaviour: theory and application. Cheltenham: Edward Elgar.

Sunderland, D. (1999). 'Objectionable parasites': the crown agents and the purchase of Crown Colony government stores, 1880-1914. Business History, 41(4), 21-48.

Valério, N. (1984). A companhia confiança nacional 1844-1846. Revista de História Económica e Social, 13, 67-92.

Wright, C. (1977). Financing public goods and residential location. Urban Studies, 14(1), 51-58.

Zerbe, R. Jr., \& McCurdy, H. (1999). The failure of market failure. Journal of Policy Analysis and Management, 18(4), 558-578. 